Szymon Swoboda

\title{
Średniowieczne relikty kultu św. Kingi. Historia i aranżacja kaplicy św. Kingi przy kościele klasztornym sióstr klarysek w Starym Sączu
}

Ulokowany w widłach Popradu i Dunajca Stary Sącz poprzez przywilej księcia Bolesława Wstydliwego nadany Kindze wraz z Ziemią Sądecką stał się miastem, z którym od tamtej pory związała ona swoje losy aż do śmierci. I vice versa, to Sącz aż do dnia dzisiejszego jest tą miejscowością, która nierozerwalnie tworzyła i tworzy swą historię, wykorzystując dzieje swej Pani ${ }^{1}$. Przede wszystkim stał się on centrum kultowym św. Kingi, wpisanym w lokalną i ponadlokalną topographia sacra. Głównym ośrodkiem kultu stał się klasztor Panien Ubogich, w jego obrębie zaś - grób Świętej Założycielki, mieszczący się w kaplicy przyklasztornego kościoła. Stanowiąc axis mundi, otworzył Niebo na łaski dla tłumnie przybywających pielgrzymów. Kaplica ta od początku swego powstania funkcjonowała jako szczególne miejsce - sanktuarium oraz mauzoleum fundatorki - co staram się wyłożyć w niniejszym artykule.

\section{Historia i dyspozycja kościoła}

Przyjmuje się, że budowa kościoła przebiegała w dwóch zasadniczych fazach: I (1280-1292) - od fundacji klasztoru do śmierci Kingi; II (1328-1332) - zakończona konsekracją przez biskupa krakowskiego Jana Grota ${ }^{2}$. Prace

1 Sącz stał się od XIII/XIV w. znaczącym ośrodkiem kultury na Podkarpaciu (klasztor był m.in. jednym z pierwszych ognisk kształcenia kobiet na ziemiach polskich); vide U. Janicka-Krzywda, Postać bł. Kingi w folklorze słownym Polski Południowej, „Nasza Przeszłość” 1997, nr 88, s. 37; S. Rosól, Święta Kinga, jej klasztor i miasto Sącz Stary, Nowy Sącz 1892, s. 26-27; M. Kornecki, W kręgu sztuki klasztoru starosądeckich klarysek, „Currenda” 1981, nr 5-8, s. 139.

2 Ważniejsze opracowania tego tematu, vide P. i T. Łopatkiewiczowie, Stanisława Tomkowicza Inwentarz zabytków powiatu sądeckiego, t. 1-2, Kraków 2007; Z. Beiersdorf, B. Krasnowolski, Architektura i urbanistyka miasta Starego Sącza, [w:] Ikonografia Starego i Nowego Sącza, red. A. Florek, Nowy Sącz 2005, s. 5-14; Architektura 
wykończeniowe w kościele trwały jeszcze w 2 poł. XIV w. Datę fundacji założenia klasztornego - rok 1280 - można przyjąć jednocześnie jako czas rozpoczęcia budowy murowanego kościoła. W 1285 r. arcybiskup Jakub Świnka dokonał pierwszej konsekracji i nadał czterdziestodniowe odpusty wszystkim, którzy w wyznaczone święta nawiedzą Stary Sącz ${ }^{3}$. Należy przypuszczać, że poświęcenie dotyczyło samego prezbiterium, które zostało wybudowane jako pierwsze i pełniło funkcję oratorium ${ }^{4}$. Część prezbiterialna uznawana jest $\mathrm{z}$ tego względu za najstarszą, co zdają się potwierdzać elementy kamieniarki oraz zespół przedstawień o cechach późnoromańskich, wyrytych w tynku na jego północnej ścianie ${ }^{5}$. Tradycja natomiast upatruje najstarszych zabytków w obrębie kaplicy Kingi, co jest zrozumiale w świetle symboliki centrum kultowego.

Kościół jest budowlą gotycką, orientowaną, jednonawową, opiętą zewnętrznymi szkarpami, z wydłużonym pięcioprzęsłowym korpusem i krótkim półtoraprzęsłowym, węższym i zamkniętym trójboczne prezbiterium. Wnętrze korpusu ukształtowane jest w sposób wieloczłonowy i dzieli się na dwie zasadnicze części: pierwszą od strony prezbiterium stanowi krótka dwuprzęsłowa nawa, natomiast część druga jest trójprzęsłowa i dwukondygnacyjna. Górną kondygnację stanowi chór muzyczny i oratorium zakonne otwarte do nawy (otwarcie ma formę ostrołukową z maswerkiem). Dolna kondygnacja to dwunawowa hala nakryta sklepieniem krzyżowo-żebrowym, wspartym na filarze środkowym, ustawionym w osi kościoła (tzw.

gotycka w Polsce, red. M. Arszyński, T. Mroczko, A. Włodarek, t. 1-2, Warszawa 1995, s. 214-215, 516; P. Pencakowski, Gotyckie kościoły zakonu św. Franciszka w Starym i Nowym Saczu, „Kwartalnik Architektury i Urbanistyki” 1991, nr 36, z. 2, s. 83-102; B. Kumor, Fundacja starosądeckiego klasztoru i parafie na Sądecczyźnie fundowane przez pp. Klaryski, „Tarnowskie Studia Teologiczne” 1987, nr 10, s. 157-164; Z. Beiersdorf, B. Krasnowolski, Stary Sacz. Zarys historii rozwoju przestrzennego, KrakówWrocław 1985; Materiały do dziejów kościoła klasztornego S.S. Klarysek w Starym Sączu, „Rocznik Sądecki” 1982, nr 17, s. 291-296; Sztuka Starego Sacza, [w:] Historia Starego Sącza od czasów najdawniejszych do 1939 r., red. H. Barycz, Kraków 1979, s. 303-340; W. Bazielich, Stary Sącz i jego zabytki, Kraków 1961.

3 B. Kumor, Fundacja..., s. 162.

4 Rzecz częsta m.in. w kościołach mendykanckich zakonów męskich, gdzie w ten m.in. sposób tłumaczy się kwestię powstawania długich prezbiteriów; vide M. Machowski, Architektura Franciszkanów w Polsce w XIII w., [w:] Zakony franciszkańskie w Polsce. Franciszkanie w Polsce średniowiecznej, cz. 2, 3, red. J. Kłoczowski, Lublin 1982, s. 198-199; A. Grzybkowski, Zagadnienie długich chórów kościołów mendykanckich w Europie środkowo-wschodniej w XIII w., [w:] Zakony..., s. 227-247.

5 M. Kornecki, $W$ kręgu..., s. 141. 
kapitularz). Kościół do dziś zachował gotycki detal architektoniczno-plastyczny - ostrołukowe portale, okna z maswerkami oraz sklepienia żebrowe ze wspornikami ${ }^{6}$. Rodzaj podparcia sklepień na wspornikach w mniej więcej $2 / 3$ wysokości nawy, a nie na sięgających do posadzki filarach i służkach oraz dość duża płaszczyzna ścian ożywiona jedynie otworami okiennymi, wskazują na formy tzw. gotyku redukcyjnego. W późniejszych wiekach średniowieczna bryła kościoła wzbogacona została dekoracją nowożytną.

Przedstawiony układ przestrzenny był podyktowany surową regułą klasztorną, bezwzględnie nakazującą odseparowanie chóru i oratorium od reszty kościoła, co miało wpływ na umieszczenie ich jako obszernej empory w zachodniej części korpusu. Analogii w tym wypadku dostarczają inne założenia żeńskich zakonów klauzurowych, m.in. dominikanek w Imbach (koniec XIII w.), klarysek w Dürnstein (1306-1326) i kościół klarysek w Óbudzie (1334-1349) ${ }^{7}$. Świątynie te odróżniają się od franciszkańskich i dominikańskich kościołów założeń męskich. Brak w nich wydłużonej zamkniętej prosto partii prezbiterialnej, tak charakterystycznej dla konwentów brackich. Pojawiają się natomiast wydzielone przestrzenie, objęte klauzurą zakonną, które połączone są z pozostałą - mieszkalną - częścią klasztoru8. Jak zauważa Andrzej Grzybowski, budowle mendykanckie, powstające w Polsce ok. 1300 r. charakteryzowała znaczna różnorodność - nie łączyły ich jakieś wspólne cechy ponadregionalne, nie podporządkowywały się także lokalnej tradycji stylowej, która była zbyt słaba na terenach zarówno Małopolski, jak i Wielkopolski9 .

6 Pierwotnie kościół przekrywały sklepienia krzyżowo-żebrowe nad prezbiterium i kapitularzem, natomiast nawa i oratorium przekryte były stropami (zastąpione przez sklepienia późnogotyckie w nawie i barokowe w oratorium); vide Z. Beiersdorf, B. Krasnowolski, Architektura kościoła i klasztoru sióstr klarysek w Starym Saczu, „Currenda” 1981, nr 5-8, s. 135.

7 Ibidem; E. Śnieżyńska-Stolot, Odkrycie klasztoru Klarysek i grobu królowej Elżbiety Łokietkówny na Węgrzech, „Biuletyn Historii Sztuki” 1979, nr 51, z. 1, s. 21-26.

8 W Sączu, jak i w Starej Budzie, empora oratorium zbliżona w planie do kwadratu umieszczona jest w zachodniej części korpusu ponad przestrzenią wspartą na słupie centralnym. Natomiast m.in. w praskim klasztorze na Františku i klasztorze w Gnieźnie empora mieściła się w dobudowanej do kościoła braci franciszkanów od północy świątyni sióstr i zajmowała 3/5 przestrzeni ponad nawą. Przestrzeń ta otwarta była arkadą ku ołtarzowi i małymi przezroczami od południa ku nawie kościoła brackiego; vide A. Grzybkowski, Architektura polska około roku 1300, [w:] Polska około roku 1300. Państwo, społeczeństwo, kultura, red. W. Fałkowski, Warszawa 2003, s. 181-182.

$9 \quad$ Ibidem, s. 184. 


\section{Historia i dyspozycja kaplicy}

Kaplica św. Kingi (pierwotnie p.w. Najświętszej Maryi Panny) wzniesiona jest przy nawie od strony południowej. Została połączona przejściem z sąsiadującą z nią lokalnością na planie kwadratu, zwaną konfesjonałem, przez której okno zakonnice przysłuchiwały się Eucharystii. Od strony kościoła kaplica oddzielona jest kutą kratą, wstawioną w nowożytny portal. Jest to budowla o wydłużonym planie, podzielona na dwie części: większą - właściwą oraz mniejszą - stanowiącą osobny chór. Podział ten odzwierciedlają sklepienia krzyżowożebrowe (o przekroju takim samym jak w prezbiterium kościoła, co sugeruje ich powstanie $\mathrm{w}$ pierwszej fazie budowy), ustanowione $\mathrm{w}$ dwa przęsła przedzielone żebrowym łukiem jarzmowym. Żebra opierają się na wielobocznych wspornikach wychodzących przed lico muru. Zwraca uwagę nierówny układ żeber w partii wschodniej, który być może wynika z przebudów w obrębie kaplicy wykonanych w XVI-XVII w., co sugerują herby ówczesnych biskupów krakowskich, umieszczone na zwornikach: Trąby - Jerzego Radziwiłła oraz Ciołek - Bernarda Maciejowskiego. W ścianie zachodniej zachował się gotycki portal ostrołukowy z ok. 1400 r., prowadzący z przedsionka do kaplicy ${ }^{10}$.

Według tradycji klasztornej, Stary Sącz stał się miejscem pielgrzymek zaraz po śmierci Kingi (1292). Wspomina o tym spisana około 1329 r. pierwsza kronika cudów. Na jej podstawie można przyjąć, że najstarsze nawiedzenie grobu Kingi miało miejsce w roku $1307^{11}$. Wtedy miała miejsce pielgrzymka ex-voto, za uzdrowienie dziewięcioletniej Dobrosławy - córki komesa Marcina ze Szczyrzyca ${ }^{12}$. Rok tego zdarzenia jest więc pierwszą cezurą czasową, wskazującą na funkcjonowanie w kościele klasztornym specjalnego miejsca kultu. Późniejszy hagiograf Kingi - Marcin Frankowic - twierdzi, iż w tym właśnie roku dokonano pierwszej translacji świętych szczątek

10 P. i T. Łopatkiewiczowie, Stanisława Tomkowicza..., s. 230.

11 P. Mojecki, Żywot S. Kunegundy zakonu świętey Klary Xięzny Polskiey, Kraków 1617, s. 212; C. Niezgoda, OFMC, Święta Kinga, żywot hagiograficzny, Stary Sącz 1999, s. 275; S. Fischer, L. Kowalski, Żywot bł. Kingi i dzieje jej kultu, Tarnów 1992, s. 112.

12 „Będąc tedy na tej obiecanej drodze, skoro wpółmili jeszcze klasztor, w którym Świętej Bożej Błogosławione ciało odpoczywa obaczyli, krzyżem na twarz swoie na ziemie padła, o uzdrowienie swej głuchoty prosząc, tamże zarazem pociechę odniosła i zdrowa doskonale została”, P. Mojecki, Żywot..., s. 214. C. Niezgoda przywołuje również fragment z pierwszego żywota Kingi: „W połowie mili wnet, jak tylko dziecko ujrzało miejsce grobu świętego ciała, upadło na ziemię prosząc panią Kingę, by raczyła okazać mu zwyczajną swą miłość; wtedy natychmiast odzyskało sprawność uszkodzonego słuchu”; vide C. Niezgoda, OFMC, Święta Kinga..., s. 275. 
księżnej-fundatorki ${ }^{13}$. Nie wiadomo natomiast, na czym ta translacja miałaby polegać. Faktem jest, że wymieniona data łączy się również ze wspomnianą pierwszą udokumentowaną pielgrzymką do grobu Kingi, który być może został właśnie w jakiś konkretny sposób wydzielony. Wydaje się to jednak sprzeczne z tym, co odnotowuje w XV w. Jan Długosz.

Stary Sącz był celem pielgrzymów na długo przed oficjalnym uznaniem kultu (1690). Miejsce to odwiedzały m.in. tak dostojne persony jak żona Władysława Łokietka Jadwiga (pochowana w Starym Sączu) oraz córka Elżbieta (pochowana w kościele klarysek w Óbudzie) ${ }^{14}$. Mimo to w XV w. nie może być jeszcze mowy o jakimś osobnym mauzoleum Kingi, a jej kości leżały wciąż w miejscu, gdzie została pochowana po śmierci, o czym świadczą słowa Długosza, iż „Ciału iey świętemu, chociay wielkimi cudami oświeconemu, blisko już dwu set lat w ziemi leżeć dopuszcza"15.

Jaki był pierwszy grób Pani Sądeckiej, nie wiadomo. Jeżeli brać dosłownie przytoczone słowa kronikarza, był to grób ziemny, a najpewniej jakaś nisza znajdująca się pod posadzką, gdzie złożona została trumna ze szczątkami. Tezę taką wysunęli Stanisław Fischer i Ludwik Kowalski, wskazując jednocześnie, że miałaby się ona znajdować pod posadzką kaplicy: „Zwłoki jej pochowano pod posadzką w łączącej się z kościołem kaplicy tuż przy oknie, przy którym zakonnice przyjmowały Komunię św. Grób przykryto płytą kamienną, na której żarzyły się odtąd bez przerwy ofiarne świece [...]"16. Przypuszczać należy, iż miejsce to znajdowało się przy południowej ścianie korpusu kościoła, w kaplicy św. Kingi, pierwotnie pod wezwaniem Najświętszej Maryi Panny.

Niezwykle interesująca (i niewyjaśniona) jest kwestia odnosząca się do funkcji mauzoleum, jaką mogła spełniać kaplica. Czy księżna Kinga przygotowywała kaplicę na miejsce swego spoczynku i ewentualnie pochówku swych krewnych dynastycznych? Na pewno jej wolą było spocząć w murach swej fundacji, nie wiadomo tylko, w jakim charakterze - księżnej-fundatorki czy pokornej członkini konwentu. Badacze wskazują, że kaplica „była pomyślana, jak się wydaje, jako kaplica grobowa fundatorki" ${ }^{17}$. Do wysunięcia takiej hipotezy zmusza niejako charakter i tradycja zakonów franciszkańskich,

13 I. M. Frankowic, Wizerunek Świętey Doskonałości... w Wielkiey Słudze Boskiey Błogosławioney Kunegundzie... jaśniejący, Kraków 1718, s. 221.

14 M. Kornecki, $W$ kręgu..., s. 140.

15 Cytat pochodzi z nowożytnego przekładu dzieła J. Długosza autorstwa P. Mojeckiego; vide P. Mojecki, Żywot..., s. 2; również: S. Fischer, L. Kowalski, Żywot..., s. 115.

16 S. Fischer, L. Kowalski, Żywot..., s. 109.

17 Z. Beiersdorf, B. Krasnowolski, Stary Sacz..., s. 34. 
które w wieku XIII i XIV były niezwykle silnie związane z rodami panującymi - w tym z dworami książąt piastowskich - których członkowie byli donatorami założeń oraz członkami konwentu. „Kościoły klasztorne, fundowane przez dynastię pełniły rolę nekropoli dla rodziny i potomków fundatora. Jeżeli chowano w nich świeckich przedstawicieli dynastii to w wypadku członków konwentu danego klasztoru musiało to być regułą"18.

Kaplica św. Kingi wraz ze wspomnianym konfesjonałem, należą do pierwotnej koncepcji budowlanej z XIII w. ${ }^{19}$ Według tradycji, konfesjonał z nadbudowaną nad nim w XVII w. kaplicą Loretańską znajdują się w miejscu pierwotnej rezydencji Kingi, częściowo ją adaptując ${ }^{20}$. Zbigniew Beiersdorf i Bogusław Krasnowolski zwrócili uwagę, że cela Kingi mogła znajdować się w bezpośrednim sąsiedztwie korpusu nawowego, co staje się przekonujące w zestawieniu z kościołem ss. Klarysek w Pradze. W programie założenia znalazło się przyległe do świątyni niewielkie palatium księżnej Agnieszki - fundatorki rozbudowy tego kościoła w latach 1238-1250 ${ }^{21}$. Mogła tam mieszkać przy klasztorze sama księżna, zaś po śmierci w tym samym miejscu utworzona została jej kaplica grobowa. Analogie nasuwają się również w wypadku kaplicy królowej Elżbiety Łokietkówny w węgierskim kościele w Óbudzie, która była usytuowana, podobnie jak w Starym Sączu, po południowej stronie korpusu i włączona w obręb klasztoru ${ }^{22}$. Podobieństw dostarcza również kościół w Imbach, gdzie w kaplicy św. Katarzyny znajdują się krypty dynastów.

Wspomniane wcześniej, przy okazji opisu kaplicy starosądeckiej, wyodrębnione przęsło z chórem sugeruje funkcję prywatnego oratorium, które jednocześnie mogło pomieścić mauzoleum z grobem fundatorki lub nawet

18 K. Jasiński, Franciszkańskie pochowki Piastów, [w:] Zakony..., s. 182. W innym miejscu autor stwierdza: „ostatecznie można przyjąć, że w klasztorach franciszkańskich zostało pochowanych z całą lub z niemal całą pewnością 63 przedstawicieli dynastii piastowskiej"; vide ibidem, s. 190.

19 Świadczą o tym: wątki murów oraz brak zarysów szkarp od strony południowej. Dekoracja kamieniarska sklepień analogiczna do tej w prezbiterium wskazuje na czternastowieczną genezę w duchu późnogotyckim.

20 Z. Beiersdorf, B. Krasnowolski, Stary Sącz..., s. 32; idem, Architektura..., s. 135. Inne znów informacje przytacza nam treść wizytacji z czasów kardynała Radziwiłła. Mianowicie w XVI w. ówczesna tradycja klasztorna wskazywała na jeden z drewnianych budynków, jako infirmerię, w której Kinga spędziła swe ostatnie chwile i miała dokonać żywota. Wszystko to jednak pozostać musi w sferze domysłów.

21 Z. Beiersdorf, B. Krasnowolski, Stary Sącz..., s. 34.

22 E. Śnieżyńska-Stolot, Odkrycie..., s. 23-24. 
z grobami jej krewnych ${ }^{23}$. Wszak kaplica ta została uznana za najważniejsze miejsce dla sądeckiego sacrum.

Po apelu J. Długosza doszło do wyjęcia szczątków Kingi z pierwotnego grobu. Pierwsze mauzoleum księżnej można datować najwcześniej na koniec lat osiemdziesiątych XV w., a inicjatorem jego budowy miałby być biskup krakowski Jan Rzeszowski, sprawujący ten urząd w latach 1472-148824. O grobowcu tym nie wiemy natomiast praktycznie nic. Lakoniczne wzmianki zawiera opis z 1682 r.:

W kaplicy tej na północ przy powyższej kracie znajdował się dawny grób b. Kunegundy, wystawiony na kształt ołtarza lub pomnika, długiego prawie na cztery łokcie i wzniesionego ponad ziemią, w którym po podniesieniu zwłok b. Kunegundy takowe od niepamiętnych czasów w cynowej trumnie ze czcią pochowane zostały ${ }^{25}$.

W dalszej części znajduje się opis sugerujący datację tego obiektu: „Przysięgli majstrowie murarscy oświadczyli, że grobowiec ten musi już mieć przeszło dwieście lat, bo jego ścian budowa, kształt cegieł i skład cementu już od dwustu lat nie są w użyciu"26. Prócz owej trumienki, wykonać miano wtedy srebrną skrzynkę na relikwie głowy, którą wystawiano na tym grobowcu dla uczczenia jej przez lud, który ofiarował swoje wota i uciekał się w potrzebach swoich do przyczyny b. Kunegundy ${ }^{27}$.

O nasilającym się kulcie Pani Sądeckiej świadczą też ukazujące się pod koniec XV w. jej wizerunki, ukazujące ją jako świętą. Dwa najstarsze zachowane do naszych czasów to rzeźba z ok. 1470 r. (ryc. 4 i 5) oraz obraz z ok. 1500 r. Opisy źródłowe i datacja obiektów pozwalają łączyć powstanie tych artefaktów z tworzeniem wystroju pierwszego mauzoleum w kaplicy św. Kingi.

Wspomniany rzeźbiarski wizerunek Kingi, umieszczony obecnie we wnęce ołtarza pod jej wezwaniem, był i jest najstarszym, tak monumentalnym

23 W kryptach klasztornych spoczęli bowiem także węgierski książę Andrzej, młodsza siostra Kingi - Konstancja oraz Jadwiga, wdowa po królu Władysławie Łokietku; patrz: Z. Beiersdorf, B. Krasnowolski, Architektura..., s. 7-8.

24 S. Fischer, L. Kowalski, Żywot..., s. 116.

25 Opis dokonany na podstawie łacińskiego rękopisu akt sporządzonych przez komisję procesu beatyfikacyjnego z roku 1682: „Processus novus particularis in causa beatificationis seu canonisationis servae Cunegundis ducissae et reginae Poloniae [...]”. A. Popławski, Ś. Kunegunda i siostry jej B. Helena czyli Jolenta i B. Małgorzata, Kraków 1881, s. 287; K. Szwarga, Dzieje kultu Bł. Kingi w Polsce, Lublin 1969, s. 27.

26 A. Popławski, S. Kunegunda..., s. 288.

27 Ibidem, s. 287. 
i wyraźnie kultowym jej przedstawieniem ${ }^{28}$. Drewniana, polichromowana, naturalnej wielkości (wys. $156 \mathrm{~cm}$ ) figura jest wyobrażeniem świętej jako księżnej, fundatorki oraz zakonnicy. Przyjmuje się, że ów wizerunek mógł powstać na podstawie starszych, niezachowanych do dzisiaj obiektów ${ }^{29}$. Rzeźba ta mogła też brać udział w pierwszym wyniesieniu szczątków Kingi $\mathrm{z}$ grobu, po $1480 \mathrm{r}$.

Kinga przedstawiona w ujęciu frontalnym, en pied, przyodziana jest w strój zakonny, na który narzucony jest płaszcz. Szaty utrzymane zostały w złotej kolorystyce. W prawej ręce, zgodnie ze średniowieczną tradycją ikonograficzną, Święta trzyma model kościoła ${ }^{30}$, w lewej zaś berło. Głowę jej wieńczy mitra książęca, będąca jednakże elementem zrekonstruowanym. Kinga stoi na postumencie w formie odwróconej korony, co - według Mariana Korneckiego - sugeruje symboliczne przedstawienie jej jako zakonnicy (świętej), odrzucającej godność świecką. Według rękopisów z 1684 r., „starożytny posąg” św. Kingi był otoczony od wieków niezwykłą czcią, zarówno klarysek, jak i okolicznego ludu. Do początków XVII w. rzeźba przechowywana była w kaplicy w „starożytnej malowanej szafie”31 i wyjmowana raz na rok w dzień św. Kingi:

Posąg ten za nim go na ołtarzu postawiono, przechowywany był od niepamiętnych czasów w tejże kaplicy po stronie wschodniej w szafie pomalowanej i częściowo pozłacanej. W święto rzeczonej sługi Bożej corocznie stawiano go na dawnym grobowcu przy kracie dla nabożeństwa ludu ${ }^{32}$.

28 M. Kornecki, W kręgu..., s. 143.

29 D. Śladecki, Ikonografia błogosławionej Kingi w sztuce na terenie diecezji tarnowskiej, „Currenda” 1989, nr 7-9, s. 379.

30 S. Tomkowicz zwracał uwagę, że model kościoła nie wykazuje podobieństwa do starosądeckiej świątyni p.w. Św. Trójcy. Kościół ma cechy idealne, nieodnoszące się do konkretnej budowli. Zastosowanie formuły ideowej, polegającej na umieszczeniu w dłoniach świętej modelu kościoła gotyckiego, jest zapewne zapożyczeniem symbolicznym, wywodzącym swoje bezpośrednie inspiracje z ikonografii świętej Jadwigi Śląskiej; vide P. i T. Łopatkiewiczowie, Stanisława Tomkowicza..., s. 232; R. Ślusarek, S. Stompel, Święta Kinga z Modelem kościoła Gotyckiego, [w:] Ikonografia Starego i Nowego Sącza, red. A. Florek, Nowy Sącz 2005, s. 47; S. Fischer, L. Kowalski, Żywot..., s. 266, przyp. 59.

31 Szafa nie zachowała się, jednak można przypuszczać, że posąg mógł być pierwotnie elementem środkowej części jakiejś nastawy ołtarzowej. S. Tomkowicz sugerował, iż rzeźba została zabrana z nastawy ołtarzowej kościoła w Kamionce, gdzie pusta szafa środkowa mieściła wcześniej jakieś przedstawienie rzeźbiarskie; vide P. i T. Łopatkiewiczowie, Stanisława Tomkowicza..., s. 232.

32 A. Popławski, Ś. Kunegunda..., s. 293; S. Fischer, L. Kowalski, Żywot..., s. 122. 
Figura ta przez wieki pełniła funkcję kultową i uznawana była za wierne przedstawienie Kingi ${ }^{33}$. Podkreślają to akta komisji, w których na temat posągu napisano, że „przedstawia on postać i rysy b. Kunegundy”. Gdzie indziej znów czytamy: „Wedle opowiadań i tradycji jeszcze za życia świętej wykonano pokryjomo ten posąg i ma wiernie przedstawiać jej figurę, a nawet rysy"34.

Najstarszy malarski wizerunek Kingi, łączony z warsztatem tzw. Mistrza Świętych Franciszkańskich z Nowego Sącza i pochodzący z tryptyku z ok. 1500 r., ukazuje ją jako świętą i orędowniczkę. Musiał odgrywać swego czasu znaczącą rolę kultową, gdyż znajdował się w Kaplicy św. Kingi, na co wskazuje opis z 1682 r.:

W kaplicy tej od najdawniejszych czasów wystawionym był ołtarz pod tytulem b. Kunegundy z obrazami Najświętszej Maryi Panny w środku, a ś. Klary $i$ b. Kunegundy po bokach, który przed osiemdziesięciu laty [...] rozebrany a po spaleniu miasta do kaplicy ś. Rocha w temże mieście przeniesiony został35.

Kinga, przedstawiona jako alter ego św. Klary, została ukazana tak jak ona na tle pokrytym złoconym grawerunkiem, whabicie sióstr ubogich, z aureolą wokół głowy, w której minuskułami wypisano: „Sancta Kunegu[ndis]"36. Ołtarz ten znajdował się najprawdopodobniej przy południowej ścianie kaplicy naprzeciw kraty, w miejscu obecnej nowożytnej nastawy.

\section{Aranżacja gotyckiej kaplicy w okresie nowożytnym}

Na koniec XVI w. przypada wielka reforma klasztoru, przeprowadzona przez biskupa Jerzego Radziwiłła, który wówczas dokonał przebudowy kaplicy św. Kingi $^{37}$. Mauzoleum Radziwiłła było częściowo drewniane, dobudowane do

\footnotetext{
S. Fischer, L. Kowalski, Żywot..., s. 122.

C. Bogdalski, Bł. Kinga, jej żywot i dzieła, Kraków 1892, s. 180.

A. Popławski, S. Kunegunda..., s. 288

36 Napis w rzeczywistości wykonany został skrótowo i brzmi: Sancta Kunegu.

37 Jak wspominają źródła, kardynał przebudowując dotychczasowy grób „[...] zniósł ten pomnik, pozostawiając tylko dla zachowania pamiątki, część jego przyległą do ściany na półtora łokcia długą i szeroką, w której to części wybić rozkazał framugę mogącą wygodnie pomieścić w sobie rzeczone relikwie. Pomalowano i ozdobiono ją ze wszystkich stron i umieszczono w niej powyższe relikwie w trumience cynowej, a zamknięto kratą żelazną, pomalowaną, przez którą widać je było. Nad tem zaś postawił srebrny relikwiarz z głową świętej”; vide A. Popławski, Ś. Kunegunda..., s. 288.
} 
grobowca z XV w. Inwestycja ta miała miejsce w latach 1595/1596-1599. Pamiątką po tym ołtarzu-grobowcu, wystawionym przez bp. Radziwiłła, jest zachowana do dziś dnia, wykonana w różowawym kamieniu tumba grobowa Kingi (ryc. 3) ${ }^{38}$. Następca Radziwiłła, bp. Bernard Maciejowski, nakazał wznieść dla relikwii zupełnie nową oprawę. Ołtarz ten postawiono w miejscu poprzedniego - datowanego na przełom XIV/XV w. - również poświęconego Kindze, w którego retabulum znajdował się wspomniany wcześniej tryptyk. Pochodzące z XVII w. opisy zamieszczone w aktach komisji beatyfikacyjnej pozwalają snuć przypuszczenia, że obecny ołtarz wykorzystuje elementy struktury wystawionej przez bp. Maciejowskiego lub jest na nim wzorowany. Ołtarz ten wykonany z drewna, pokryty mazerunkiem imitującym modny wówczas i szeroko w rzeźbie sepulkralnej wykorzystywany dębnik otrzymał formy architektoniczne ${ }^{39}$. Część środkowa ujęta została parami kolumienek o różowawym odcieniu ze złoconymi akantowymi głowicami, dźwigającymi belkowanie i trójkątny niski przyczółek. W części tego ołtarza była nisza na przechowanie relikwii „za kratami żelaznemi, pozłacanemi z obydwuch stron otwierającemi się i za tablicami czarnemi, w niektórych miejscach wyzłacanemi, które można usuwać" ${ }^{40}$. Prócz trumienki, na ołtarzu tym wystawione były jeszcze trzy relikwiarze - głowy, ręki i relikwiarz w kształcie wieży, mieszczący w sobie rozmaite pamiątki po św. Kindze (nie dotrwały do naszych czasów). Ponad niszą z trumienką, w środkowej części ołtarza, wystawiona była „starożytna figura” Kingi z 1470 r., uznawana za jej najstarszy, szlachetny konterfekt. Nad figurą tą w zwieńczeniu „nad ołtarzem i relikwiami dwaj aniołowie trzymają koronę królewską" ${ }^{41}$.

W kilkanaście lat po inwestycjach obu biskupów wnętrze kaplicy pokrył polichromią artysta klasztorny Wawrzyniec Cieszyński, zatrudniony w 1617 r. przez ksienię Zofię Boczkowską. Malowidła ukazywały m.in. anioły $z$ banderolami, na których widniały wezwania do bł. Kingi ${ }^{42}$. Niemal w sto lat później (1779) polichromie Cieszyńskiego zostały zakryte nowymi,

38 Cf. M. Kornecki, Bł. Kinga - pamiatki, obiekty kultu, dzieła sztuki. Inwentarz z terenu diecezji tarnowskiej, „Currenda” 1990, nr 1-3, 1990; P. i T. Łopatkiewiczowie, Stanisława Tomkowicza..., s. 226.

P. i T. Łopatkiewiczowie, Stanisława Tomkowicza..., s. 231.

40 A. Popławski, S. Kunegunda..., s. 289.

41 Ibidem, s. 293.

$42 \quad$ M. Kornecki, Bł. Kinga..., s. 13; W. Szczebak, Z dziejów kościoła i klasztoru oraz mecenatu artystycznego starosądeckich klarysek, „Tarnowskie Studia Teologiczne” 1987, nr 10, s. 172-173. 
wykonanymi przez Feliksa Derysarza ${ }^{43}$. Do dziś zachowały się godne uwagi pokrywające sklepienie wyobrażenia putt podtrzymujących atrybuty bł. Kingi - suknię zakonną, lilię, model kościoła i woreczek z monetami którym odpowiadają widniejące obok objaśnienia - Habit, Panna, Fundatorka, Szczodrobliwa ${ }^{44}$.

W XVII w. wzniesiony został również ujmujący monumentalny portal z czarnego marmuru, oddzielający kaplicę od klauzury. Oprawa ta z drobnymi ozdobami $\mathrm{z}$ alabastru i białego marmuru przypomina portal do kaplicy Wazów na Wawelu ${ }^{45}$. Wiktor Bazielich wskazuje, że dzieło to powstało za rządów ksieni Konstancji Apolinary Jordanówny, w początkach XVIII w. Jednakże wspomniane analogie formalne oraz przede wszystkim fragment opisu akt beatyfikacyjnych z 1682 r. zdają się zaprzeczać tej tezie: „Kaplica ta z boku styka się z kościołem, od którego oddziela ją krata żelazna pozłacana i osadzona w marmurze czarnym prześlicznej roboty w kształcie ołtarza"46.

Kaplica św. Kingi to szczególny obiekt sakralny starosądeckiego zespołu klasztornego. Narracja historyczna związana z kultem łączy ze sobą wywodzące się z tradycji klasztornej przekazy hagiograficzne $\mathrm{z}$ wątkiem historycznym. Potwierdzeń dostarczają materialne relikty związane ze średniowieczną fazą kultu. Kolejne, nowożytne fundacje - związane z aranżacją kaplicy-mauzoleum - stały się dopełnieniem zastanego kontekstu. Powstały w ten sposób wystrój był odzwierciedleniem nabożności oraz dążeń do beatyfikacji Kingi. Wiązał się z tym wydźwięk ideowy aranżacji kaplicy oraz łączone $\mathrm{z}$ tym miejscem tradycje. Zachowane elementy średniowieczne służyły jako świadectwo historyczne, potwierdzające relacje hagiograficzne i legitymizujące „odwieczność kultu”.

\section{Bibliografia}

Architektura gotycka w Polsce, t. 1-3, red. M. Arszyński, T. Mroczko, A. Włodarek, Warszawa 1995.

BAZIELICH W., Klaryski Starosądeckie a sztuki piękne w XVII i XVIII w., „Nasza Przeszłość" 1966, nr 25, s. 179-220.

BAZIELICH W., Stary Sącz i jego zabytki, Kraków 1961.

43 M. Kornecki, Bt. Kinga..., s. 13.

44 Ibidem.

45 W. Bazielich, Klaryski Starosądeckie a sztuki piękne w XVII i XVIII w., „Nasza Przeszłość” 1966, nr 25, s. 191; P. i T. Łopatkiewiczowie, Stanisława Tomkowicza..., s. 223.

46 A. Popławski, S. Kunegunda..., s. 287. 
BEIERSDORF Z., KRASNOWOLSKI B., Architektura i urbanistyka miasta Starego Sacza, [w:] Ikonografia Starego i Nowego Sacza, red. A. Florek, Nowy Sącz 2005.

BEIERSDORF Z., KRASNOWOLSKI B., Architektura kościoła i klasztoru sióstr klarysek w Starym Saczu, „Currenda” 1981, nr 5-8.

BEIERSDORF Z., KRASNOWOLSKI B., Stary Sacz. Zarys historii rozwoju przestrzennego, Kraków-Wrocław 1985.

BOGDALSKI C., Bł. Kinga, jej żywot i dzieła, Kraków 1892.

FISCHER S., KOWALSKI L., Żywot bł. Kingi i dzieje jej kultu, Tarnów 1992.

FRANKOWIC I. M., Wizerunek Świętey Doskonałości... w Wielkiey Studze Boskiey Błogosławioney Kunegundzie... jaśniejący, Kraków 1718.

GRZYBKOWSKI A., Architektura polska około roku 1300, [w:] Polska około roku 1300. Państwo, społeczeństwo, kultura, red. W. Fałkowski, Warszawa 2003, s. $155-197$.

GRZYBKOWSKI A., Zagadnienie długich chórów kościołów mendykanckich w Europie środkowo-wschodniej w XIII w., [w:] Zakony franciszkańskie w Polsce. Franciszkanie w Polsce średniowiecznej, cz. 2, 3, red. J. Kłoczowski, Lublin 1982, s. 227-247.

JANICKA-KRZYWDA U., Postać bł. Kingi w folklorze słownym Polski południowej, „Nasza Przeszłość” 1997, nr 88, s. 33-57.

JASIŃSKI A., Franciszkańskie pochówki Piastów, [w:] Zakony franciszkańskie $w$ Polsce. Franciszkanie w Polsce średniowiecznej, cz. 2-3, red. J. Kłoczowski, Lublin 1982, s. 95-143.

KORNECKI M., Bł. Kinga - pamiątki, obiekty kultu, dzieła sztuki. Inwentarz z terenu diecezji tarnowskiej, „Currenda” 1990, nr 1-3.

KORNECKI M., W kreggu sztuki klasztoru starosadeckich klarysek, „Currenda” 1981, nr 5-8, s. 139-146.

KUMOR B., Fundacja starosadeckiego klasztoru i parafie na Sądecczyźnie fundowane przez pp. Klaryski, „Tarnowskie Studia Teologiczne” 1987, nr 10, s. $157-174$.

ŁOPATKIEWICZOWIE P. i T., Stanisława Tomkowicza Inwentarz zabytków powiatu sądeckiego, t. 1-2, Kraków 2007.

MACHOWSKI M., Architektura Franciszkanów w Polsce w XIII w., [w:] Zakony franciszkańskie w Polsce. Franciszkanie w Polsce średniowiecznej, cz. 2-3, red. J. Kłoczowski, Lublin 1982, s. 198-199.

Materiały do dziejów kościoła klasztornego S.S. Klarysek w Starym Saczu, „Rocznik Sądecki” 1982, nr 17.

MOJECKI P., Żywot S. Kunegundy zakonu świętey Klary Xięzny Polskiey, Kraków 1617.

NIEZGODA C., Święta Kinga, żywot hagiograficzny, Stary Sącz 1999. 
PENCAKOWSKI P., Gotyckie kościoły zakonu św. Franciszka w Starym i Nowym Saczu, „Kwartalnik Architektury i Urbanistyki” 1991, nr 36, z. 2, s. 83-102.

POPŁAWSKI A., Ś. Kunegunda i siostry jej B. Helena czyli Jolenta i B. Małgorzata, Kraków 1881.

ROSÓŁ S., Święta Kinga, jej klasztor i miasto Sącz Stary, Nowy Sącz 1892.

SZCZEBAK W., $Z$ dziejów kościoła i klasztoru oraz mecenatu artystycznego starosądeckich klarysek, „Tarnowskie Studia Teologiczne” 1987, nr 10, s. 165-177.

Sztuka Starego Sącza, [w:] Historia Starego Sącza od czasów najdawniejszych do 1939 r., red. H. Barycz, Kraków 1979.

SZWARGA K., Dzieje kultu Bł. Kingi w Polsce, Lublin 1969.

ŚLADECKI D., Ikonografia błogosławionej Kingi w sztuce na terenie diecezji tarnowskiej, „Currenda” 1989, nr 7-9, s. 377-385.

ŚNIEŻYŃSKA-STOLOT E., Odkrycie klasztoru Klarysek i grobu królowej Elżbiety Łokietkówny na Węgrzech, „Biuletyn Historii Sztuki” 1979, nr 51, z. 1, s. 21-26. 


\section{Aneks}

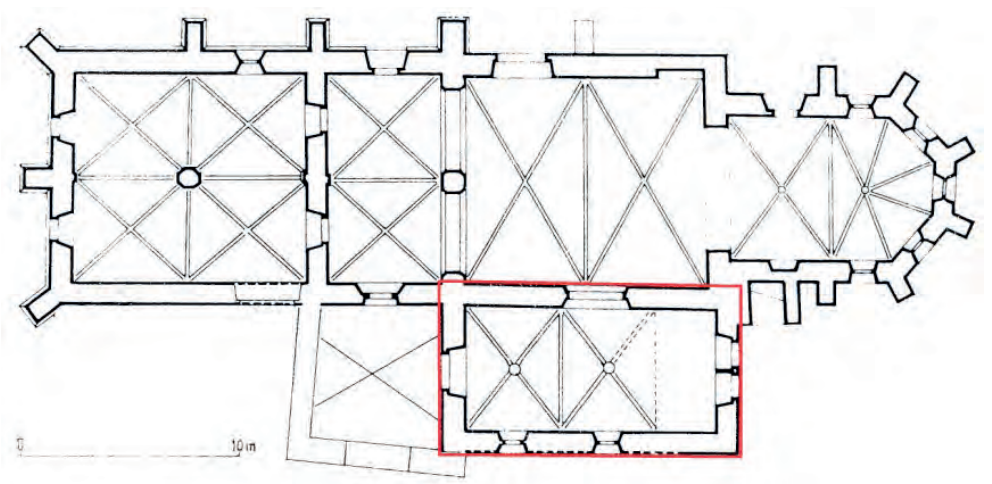

Ryc. 1. Plan kościoła w Starym Sączu z zaznaczoną obrysem kaplicą p.w. św. Kingi. Źródło: Architektura gotycka w Polsce, t. 2, red. A. Włodarek, Warszawa 1995, s. 516

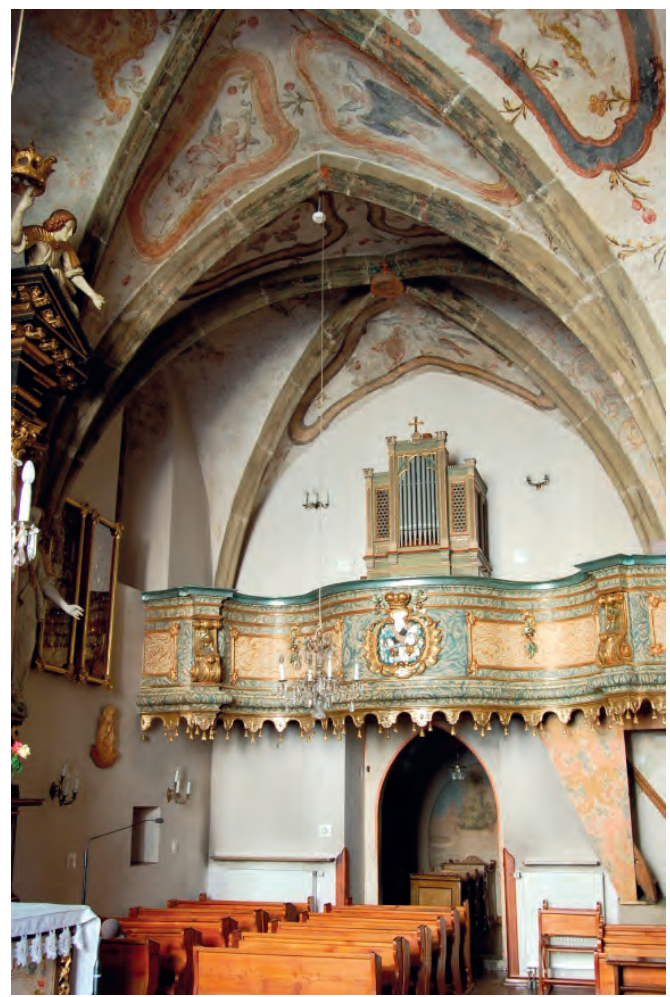

Ryc. 2. Wnętrze kaplicy - widok na chór. Na stropie widoczne polichromie z XVIII w. Fot. Archiwum cyfrowe Sióstr Klarysek w Starym Sączu 


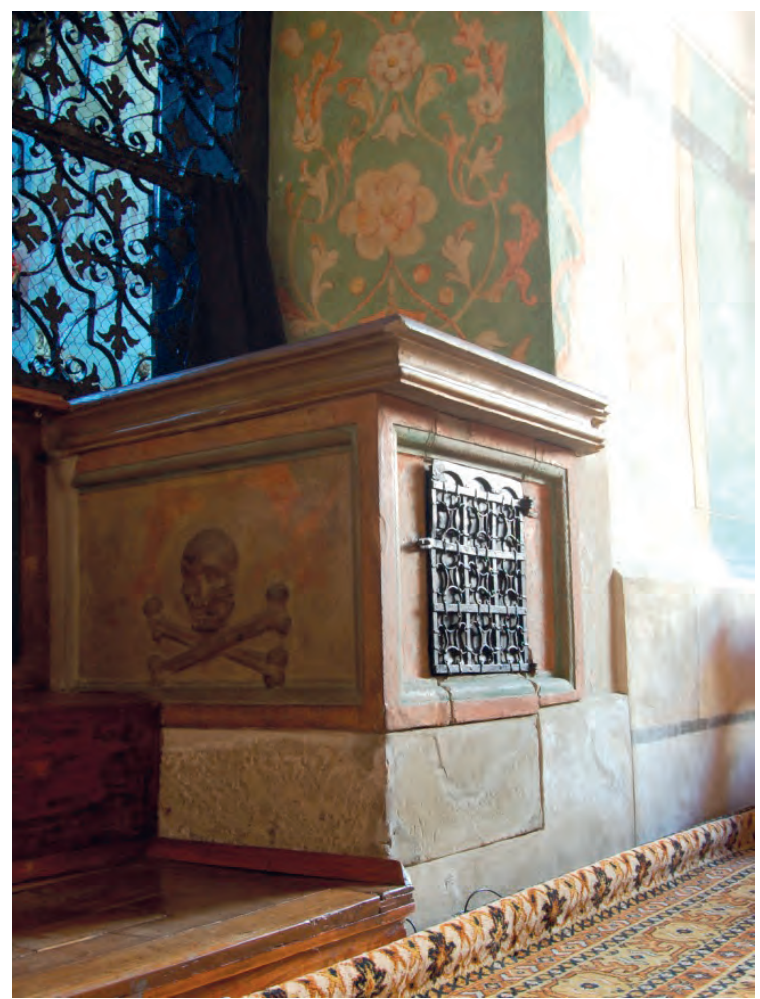

Ryc. 3. Tumba grobowa Kingi - pozostałość po mauzoleum fundacji bp. Radziwiłta. Fot. Archiwum cyfrowe Sióstr Klarysek w Starym Sączu

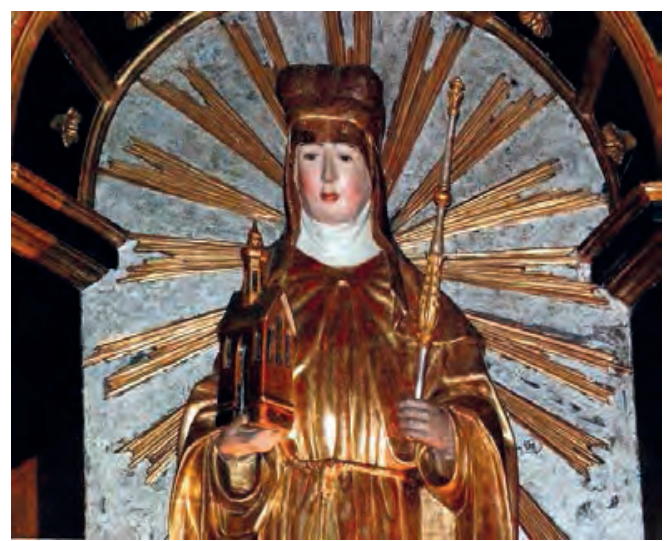

Ryc. 4. Fragment średniowiecznej figury św. Kingi z ok. 1470 r.

Fot. Archiwum cyfrowe Sióstr Klarysek w Starym Sączu 


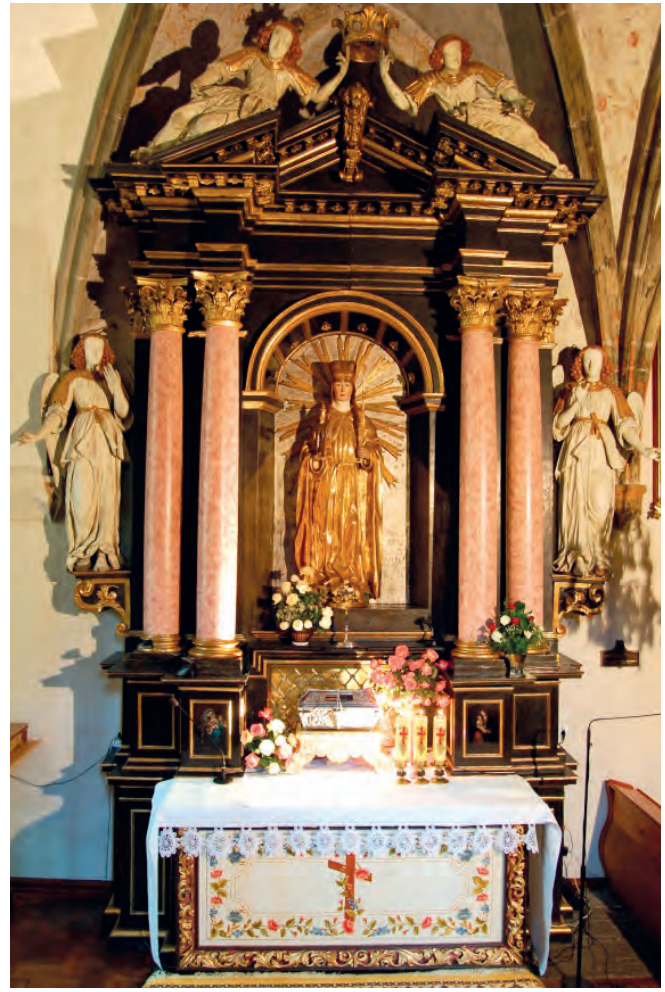

Ryc. 5. Ołtarz z figurą św. Kingi - wygląd obecny.

Fot. Archiwum cyfrowe Sióstr Klarysek w Starym Sączu 